Food Hygiene Department,

Animal Health Research Institute, Dokki, Giza.

\title{
EFFICIENCY OF BIFIDOBACTERIUM WITH/OR SALTS OF SORBIC ACID ON THE QUALITY OF CHILLED AND FROZEN FISH FILLET
}

(With 6 Tables and 12 Figures)

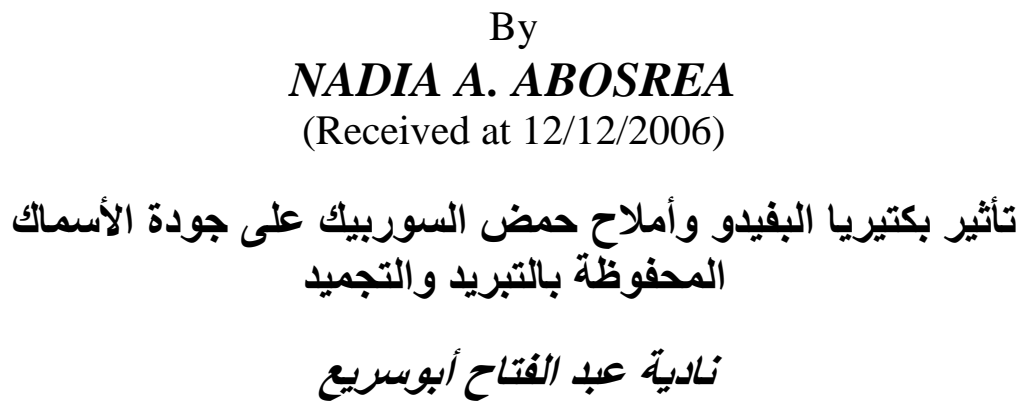

تم حفظ شر ائح السمك البلطى مقسماً إلى مجمو عتين رئيسيتين، الأولى كمجمو عة ضـابطة و أمـا

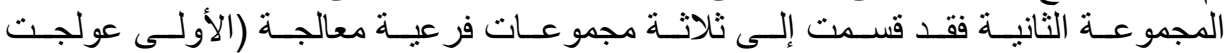

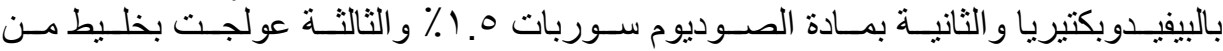

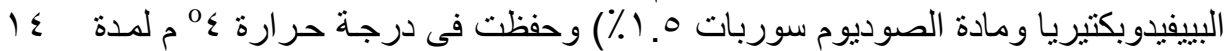

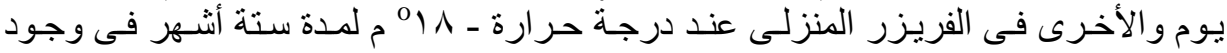

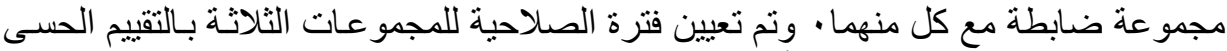

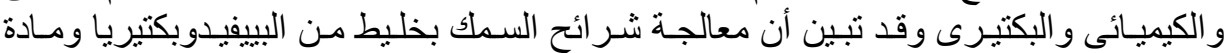

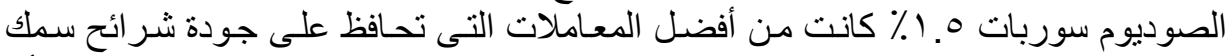

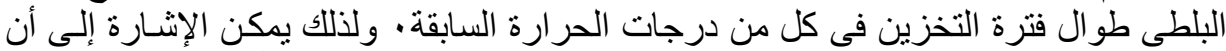

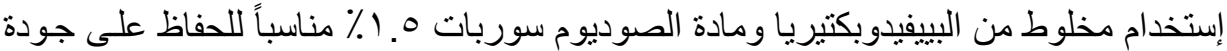

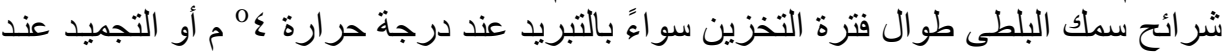

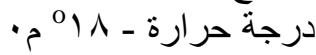

\section{SUMMARY}

Bolti fish (Tilapia nilotica) fillets were divided into two groups, $1^{\text {st }}$ group considered as a control one and the $2^{\text {nd }}$ group was subdivided into three subgroups $\left(1^{\text {st }}\right.$ group was treated with Bifidobacterial culture, $2^{\text {nd }}$ group was treated with potassium sorbate $1.5 \%$ and the $3^{\text {rd }}$ group was treated with a combination of Bifidobacterial culture and potassium sorbate $1.5 \%)$. These treated groups were stored with a control group at $4^{\circ} \mathrm{C}$ for 14 days and the other was stored at $-18^{\circ} \mathrm{C}$ for 6 months. Some of physiochemical, microbiological and organoleptic characteristics of 
Bolti fish fillets were studied and evaluated. The results indicated that using of mixture of potassium sorbate and Bifidobacterial culture maintained fish fillets in a good condition up to 24 weeks (storage period) for samples kept at $-18^{\circ} \mathrm{C}$ and improved the physiochemical, microbiological and organoleptic characteristics for samples stored at $4^{\circ} \mathrm{C}$ for 12 days. The use of combination of Bifidobacterial culture and potassium sorbate $1.5 \%$ for keeping stored Tilapia fillets stored at both $4^{\circ} \mathrm{C}$ or at $-18^{\circ} \mathrm{C}$ was recommended.

Key words: Fish, bifidobacterium, sorbic acid.

\section{INTRODUCTION}

Consumption of seafood is increasing and most consumers prefer fresh or fresh like seafood products. This high demand for seafood in restaurant, supermarkets, delicatessens and other outlets has improved market stability (Beuchat et al., 1975).

Quality and safety of refrigerated and freezed foods have been enhanced by preventing growth or destroying aerobic spoilage bacteria and foodborne pathogens during storage and handling using additives and preservatives (Gilliand and Ewell, 1983; Lindgren and Dobrogosz, 1990; Kim et al., 1995a). Bio preservatives such as bifidobacteria may control food spoilage bacteria through production of lactic acid and acetic acid as well as other antibiotic substances (Larioia and Martin, 1991; Ray, 1992; Vazquez et al., 2005). Previous works have shown that potassium sorbate effective in suppressing growth of aerobic spoilage bacteria and increase shelf life of seafoods (Godavari et al., 1987; Kondaiah et al., 1985; Mendonca et al., 1989a; Unda et al., 1990; Zhuang et al., 1996).

This study, therefore, was mainly initiated to evaluate the possibility of extending the shelf life of refrigerated and frozen fish treated with combination of bifidobacteria and food-grade organic salts.

\section{MATERIALS and METHODS}

Lot of fresh Bolti fish (Tilapia nilotica) $25 \mathrm{~kg}$ used in this experiment were purchased from El-Abour market, Cairo. Fish fillets were obtained after evisceration and removal of scales and skin of fresh fish. Fish flesh were then cut into parts and then packed in ice-box with ice ratio 1:2. The samples were directly transported to the laboratory without delay and then classified into two main groups, which they 
subdivided into two subgroups. The $1^{\text {st }}$ group was used as a control one while the $2^{\text {nd }}$ group was divided into three treated groups each was treated with Bifidobacteria culture, potassium sorbate $1.5 \%$ and combination of $1.5 \%$ potassium sorbate and Bifidobacterial culture. One of the main group was kept at cold storage at $4 \pm 1^{\circ} \mathrm{C}$ (crushed ice 1:2) through the storage period (14 days). Melted ice was drained daily and was replaced with ice when needed. Every 24 hours intervals samples were withdrawn and assed for examinations.

The $2^{\text {nd }}$ main group were packed in polyethylene bag and were immediately stored at home freezer $\left(-18^{\circ} \mathrm{C}\right)$ for 24 weeks. Two hundred gm of fish fillets were examined periodically every 2 weeks. Each sample was thawed at $10^{\circ} \mathrm{C}$ overnight prior to examination.

\section{Preparation of bifidobacteria cultures:}

Bifidobacterium infantis (ATCC 15697) was obtained from Food Technology and Dairy Department, National Research Center, Dokki, Cairo. Stock cultures were maintained in sterile skim milk medium (SM; $10 \%$ skim milk. $0.5 \%$ yeast extract and $0.5 \%$ glucose) at $37^{\circ} \mathrm{C}$ for 24 hours in an anaerobic jar.

Bifidobacteria were enumerated by pour plating appropriate serial dilutions in $0.1 \%$ peptone water with neomycin-paramycinnalidixic acid-lithium chloride agar (Teraguchi et al., 1978; Laroia and Martin, 1991) followed by incubation at $37^{\circ} \mathrm{C}$ for 48 hours in an anaerobic jar (Gas-Pack; BBL) prior to counting colonies. Bifidobacteria cultures in skim milk $\left(6.0 \times 10^{7}\right.$ to $\left.1.0 \times 10^{8} \mathrm{CFU} / \mathrm{ml}\right)$ were added at a given percentage (v/v) to fresh Tilapia nilotica, final skim milk $\mathrm{pH}$ was 4.4-4.8 alone or was thoroughly mixed with solution of $1.5 \%$ potassium sorbate (organic acid). Fish fillets were dipped for 2 minutes in $500 \mathrm{ml}$ of the treatment solution with gentle swirling using a sterile glass rode to ensure complete contact with treatment solution. Fillets were then removed from the treatment solution with sterile tongs and allowed to drain for 2 minutes on a sterile metal net. After draining the excess solution, samples were placed into sterile polyethylene bags and stored according to its group of experiment which was subjected to quality evaluation tests as the following:

\section{A- Sensory evaluation:}

The sensory evaluation was carried out according to the technique reported by More and Iriter, (1970). The items examined were appearance, consistency, tenderness, flavour, and overall eating quality. 
The quality of fish fillet were graded excellent, very good, good, medium, fair, poor and the score system points $7,6,5,4,3,2$, and 1 respectively.

\section{B- Chemical examination:}

Deterioration criteria assayed in samples of fish fillets by determining the following:

1- $\mathrm{pH}$ value was carried out according to the method of AOAC (1990) by using $\mathrm{pH}$ meter (Jenco, Digital $\mathrm{pH}$ meter 609).

2- Total Volatile Basic Nitrogen (TVBN) (mg/100gm) was determined according to the method described by FAO (1980).

\section{C- Bacteriological examination:}

The bacteriological methods were carried out according to APHA (1992).

1- Aerobic Plate Count.

2- Total Enterobacteriaceae count.

3- Enumeration of total coliforms count (MPN/gm).

4- Detection of E. coli.

5-Staphylococcus aureus count.

\section{RESULTS}

Table 1: Sensory evaluation of control and treated samples stored at $5^{\circ} \mathrm{C}$. (Mean of 3 samples).

\begin{tabular}{|l|c|c|c|c|c|c|c|c|}
\hline \multirow{2}{*}{ Time } & \multicolumn{2}{|c|}{ Control } & \multicolumn{2}{|c|}{1} & \multicolumn{2}{c|}{2} & \multicolumn{2}{c|}{3} \\
\cline { 2 - 10 } & Mean & Quality & Mean & Quality & Mean & Quality & Mean & Quality \\
\hline 0 time & 7.0 & Excellent & 7.0 & Excellent & 7.0 & Excellent & 7.0 & Excellent \\
\hline $2^{\text {th }}$ day & 5.0 & Good & 7.0 & Excellent & 7.0 & Excellent & 7.0 & Excellent \\
\hline $4^{\text {th }}$ day & 3.8 & Medium & 5.0 & Good & 5.5 & Good & 7.0 & Excellent \\
\hline $6^{\text {th }}$ day & 3.0 & Fair & 4.0 & Medium & 4.5 & Medium & 6.0 & V. good \\
\hline $8^{\text {th }}$ day & 2.0 & Poor & 3.0 & Fair & 4.0 & Medium & 5.1 & Good \\
\hline $10^{\text {th }}$ day & - & - & 2.0 & Poor & 3.0 & Fair & 4.3 & Medium \\
\hline $12^{\text {th }}$ day & - & - & - & - & 2.5 & Poor & 3.8 & Fair \\
\hline $14^{\text {th }}$ day & - & - & - & - & - & - & 3.0 & Fair \\
\hline
\end{tabular}

$1=$ Examined samples treated with Bifidobacterial culture

$2=$ Examined samples treated with Potassium sorbate $1.5 \%$

$3=$ Examined samples treated with combination of Bifidobacterial culture and potassium sorbate $1.5 \%$ 
Table 2: $\mathrm{pH}$ values and Total Volatile Basic Nitrogen (TVBN) $(\mathrm{mg} / 100 \mathrm{gm})$ of control and treated samples stored at $5^{\circ} \mathrm{C}$.

\begin{tabular}{|c|c|c|c|c|c|c|c|c|}
\hline \multirow{2}{*}{ Time } & \multicolumn{4}{|c|}{$\mathrm{pH}$} & \multicolumn{5}{c|}{ TVBN (mg/100gm) } \\
\cline { 2 - 9 } & Control & 1 & 2 & 3 & Control & 1 & 2 & 3 \\
\hline 0 time & 6.0 & 5.8 & 5.7 & 5.6 & 12.0 & 12.0 & 12.0 & 12.0 \\
\hline $2^{\text {nd }}$ day & 6.1 & 5.8 & 5.7 & 5.6 & 21.0 & 17.0 & 16.0 & 14.0 \\
\hline $4^{\text {th }}$ day & 6.4 & 5.8 & 5.8 & 5.7 & 29.0 & 23.6 & 22.0 & 19.0 \\
\hline $6^{\text {th }}$ day & 6.5 & 6.0 & 5.9 & 5.8 & 34.3 & 29.0 & 28.0 & 23.0 \\
\hline $8^{\text {th }}$ day & 6.7 & 6.2 & 6.0 & 5.9 & 40.0 & 35.2 & 33.0 & 25.0 \\
\hline $10^{\text {th }}$ day & - & 6.7 & 6.2 & 6.0 & - & 40.0 & 38.1 & 27.0 \\
\hline $12^{\text {th }}$ day & - & - & 6.6 & 6.1 & - & - & 40.0 & 28.3 \\
\hline $14^{\text {th }}$ day & - & - & - & 6.2 & - & - & - & 33.0 \\
\hline
\end{tabular}

$1=$ Examined samples treated with Bifidobacterial culture

$2=$ Examined samples treated with Potassium sorbate $1.5 \%$

$3=$ Examined samples treated with combination of Bifidobacterial culture and potassium sorbate $1.5 \%$

Table 3: Microbiological quality of control and treated samples stored at $5^{\circ} \mathrm{C}$.

\begin{tabular}{|c|c|c|c|c|c|c|c|c|c|c|c|c|c|c|c|c|}
\hline \multirow{2}{*}{ Time } & \multicolumn{4}{|c|}{$\begin{array}{l}\mathrm{APC} \\
\mathrm{CFU} / \mathrm{g}\end{array}$} & \multicolumn{4}{|c|}{$\begin{array}{c}\text { Enterobacteriaceae count } \\
\text { CFU/g }\end{array}$} & \multicolumn{4}{|c|}{$\begin{array}{l}\text { Coliforms count } \\
\text { (MPN/g) }\end{array}$} & \multicolumn{4}{|c|}{ Staphylococcus aureus count CFU/g } \\
\hline & Control & 1 & 2 & 3 & Control & 1 & 2 & 3 & Control & 1 & 2 & 3 & Control & 1 & 2 & 3 \\
\hline 0 time & $2 \times 10^{4}$ & $2 \times 10^{4}$ & $2 \times 10^{4}$ & $2 \times 10^{4}$ & $10^{3}$ & $10^{3}$ & $10^{3}$ & $10^{3}$ & 92 & 92 & 92 & 92 & $3 \times 10^{2}$ & $3 \times 10^{2}$ & $3 \times 10^{2}$ & $3 \times 10^{2}$ \\
\hline $2^{\text {nd }}$ day & $4.6 \times 10^{4}$ & $3.1 \times 10^{4}$ & $2.6 \times 10^{4}$ & $2.2 \times 10^{4}$ & $6.2 \times 10^{3}$ & $4.2 \times 10^{3}$ & $2.5 \times 10^{3}$ & $1.5 \times 10^{3}$ & 92 & 75 & 70 & 40 & $2.5 \times 10^{2}$ & $1.5 \times 10^{2}$ & $1.5 \times 10^{2}$ & $10^{2}$ \\
\hline $4^{\text {th }}$ day & $8 \times 10^{4}$ & $5 \times 10^{4}$ & $3.9 \times 10^{4}$ & $3.0 \times 10^{4}$ & $9.3 \times 10^{3}$ & $6.1 \times 10^{3}$ & $5 \times 10^{3}$ & $2.3 \times 10^{3}$ & 92 & 45 & 40 & 31 & $2 \times 10^{2}$ & $10^{2}$ & $10^{2}$ & $10^{2}$ \\
\hline $6^{\text {th }}$ day & $7.2 \times 10^{5}$ & $2.1 \times 10^{5}$ & $1.5 \times 10^{5}$ & $7.5 \times 10^{4}$ & $5.1 \times 10^{4}$ & $1.5 \times 10^{4}$ & $10^{4}$ & $9.7 \times 10^{3}$ & 110 & 35 & 31 & 25 & $1.5 \times 10^{2}$ & $10^{2}$ & $10^{2}$ & $10^{2}$ \\
\hline $8^{\text {th }}$ day & $6.2 \times 10^{6}$ & $10^{6}$ & $9.8 \times 10^{5}$ & $2.1 \times 10^{5}$ & $9.2 \times 10^{4}$ & $4.2 \times 10^{4}$ & $3.1 \times 10^{4}$ & $10^{4}$ & 120 & 25 & 25 & 23 & $1.5 \times 10^{3}$ & $10^{2}$ & $10^{2}$ & $10^{2}$ \\
\hline $10^{\text {th }}$ day & $3 \times 10^{7}$ & $3.1 \times 10^{6}$ & $1.5 \times 10^{6}$ & $4.2 \times 10^{5}$ & $3.9 \times 10^{5}$ & $9.1 \times 10^{4}$ & $5.1 \times 10^{4}$ & $1.5 \times 10^{4}$ & 140 & 23 & 21 & 11 & $3 \times 10^{3}$ & $10^{2}$ & $10^{2}$ & $<10^{2}$ \\
\hline $12^{\text {th }}$ day & $2 \times 10^{8}$ & $10^{7}$ & $9.7 \times 10^{6}$ & $8.3 \times 10^{5}$ & $7.9 \times 10^{5}$ & $1.2 \times 10^{5}$ & $9.2 \times 10^{4}$ & $3.2 \times 10^{4}$ & 170 & 21 & 11 & 9 & $4 \times 10^{3}$ & $<10^{2}$ & $<10^{2}$ & $<10^{2}$ \\
\hline $14^{\text {th }}$ day & $10^{9}$ & $10^{8}$ & $9.8 \times 10^{7}$ & $7 \times 10^{6}$ & $9 \times 10^{6}$ & $7.9 \times 10^{5}$ & $1.3 \times 10^{5}$ & $8.7 \times 10^{4}$ & 210 & 11 & 9 & $<3$ & $9 \times 10^{3}$ & $<10^{2}$ & $<10^{2}$ & $<10^{2}$ \\
\hline
\end{tabular}

$1=$ Examined samples treated with Bifidobacterial culture

$2=$ Examined samples treated with Potassium sorbate $1.5 \%$

$3=$ Examined samples treated with combination of Bifidobacterial culture and potassium sorbate $1.5 \%$ 
Table 4: Sensory evaluation of control and treated samples stored at $18^{\circ} \mathrm{C}$ (Mean of 3 samples).

\begin{tabular}{|l|c|c|c|c|c|c|c|c|}
\hline \multirow{2}{*}{ Time } & \multicolumn{2}{|c|}{ Control } & \multicolumn{2}{|c|}{1} & \multicolumn{2}{|c|}{2} & \multicolumn{2}{c|}{3} \\
\cline { 2 - 10 } & Mean & Quality & Mean & Quality & Mean & Quality & Mean & Quality \\
\hline 0 time & 7.0 & excellent & 7.0 & Excellent & 7.0 & Excellent & 7.0 & Excellent \\
\hline 2 weeks & 6.0 & V. good & 6.0 & V. good & 6.0 & V. good & 6.4 & V. good \\
\hline 4 weeks & 5.0 & Good & 6.0 & V. good & 6.0 & V. good & 6.3 & V. good \\
\hline 6 weeks & 5.0 & Good & 6.0 & V. good & 6.0 & V. good & 6.2 & V. good \\
\hline 8 weeks & 4.0 & Medium & 6.0 & V. good & 6.0 & V. good & 6.1 & V. good \\
\hline 10 weeks & 4.0 & Medium & 5.0 & Good & 6.0 & V. good & 6.0 & V. good \\
\hline 12 weeks & 3.5 & Fair & 5.0 & Good & 5.0 & Good & 6.0 & V. good \\
\hline 14 weeks & 3.0 & Fair & 4.0 & Medium & 5.0 & Good & 6.0 & V. good \\
\hline 16 weeks & 2.0 & Poor & 3.7 & Fair & 4.0 & Medium & 5.0 & Good \\
\hline 18 weeks & 1.3 & V. poor & 3.5 & Fair & 4.0 & Medium & 5.0 & Good \\
\hline 20 weeks & - & - & 3.2 & Fair & 3.8 & Fair & 4.0 & Medium \\
\hline 22 weeks & - & - & 2.9 & Fair & 3.0 & Fair & 3.5 & Fair \\
\hline 24 weeks & - & - & 2.3 & Poor & 2.5 & Poor & 3.0 & Fair \\
\hline
\end{tabular}

$1=$ Examined samples treated with Bifidobacterial culture

$2=$ Examined samples treated with Potassium sorbate $1.5 \%$

$3=$ Examined samples treated with combination of Bifidobacterial culture and potassium sorbate 1.5\%

Table 5: $\mathrm{pH}$ values and Total Volatile Basic Nitrogen (TVBN) $(\mathrm{mg} / 100 \mathrm{gm})$ of control and treated samples stored at $-18^{\circ} \mathrm{C}$.

\begin{tabular}{|l|c|c|c|c|c|c|c|c|}
\hline \multirow{2}{*}{ Time } & \multicolumn{4}{|c|}{$\mathrm{pH}$} & \multicolumn{3}{c|}{ TVBN (mg/100gm) } \\
\cline { 2 - 9 } & Control & 1 & 2 & 3 & Control & 1 & 2 & 3 \\
\hline 0 time & 5.90 & 6.50 & 5.50 & 5.5 & 12.00 & 12.00 & 12.00 & 12.00 \\
\hline 2 weeks & 5.93 & 5.60 & 5.60 & 5.63 & 15.44 & 9.80 & 8.90 & 8.70 \\
\hline 4 weeks & 6.03 & 5.70 & 5.60 & 5.65 & 17.23 & 11.30 & 9.70 & 9.20 \\
\hline 6 weeks & 6.06 & 5.80 & 5.7 & 5.71 & 20.57 & 11.60 & 11.20 & 11.00 \\
\hline 8 weeks & 6.13 & 5.90 & 5.8 & 5.75 & 22.46 & 14.30 & 11.50 & 11.20 \\
\hline 10 weeks & 6.23 & 6.00 & 5.9 & 5.78 & 25.30 & 17.01 & 14.20 & 11.50 \\
\hline 12 weeks & 6.36 & 6.10 & 6.00 & 5.80 & 27.74 & 17.90 & 17.00 & 14.00 \\
\hline 14 weeks & 6.43 & 6.20 & 6.10 & 5.90 & 30.00 & 19.70 & 17.60 & 15.22 \\
\hline 16 weeks & 6.50 & 6.30 & 6.20 & 6.00 & 32.93 & 21.80 & 19.20 & 17.00 \\
\hline 18 weeks & - & 6.40 & 6.30 & 6.10 & - & 24.30 & 24.00 & 20.60 \\
\hline 20 weeks & - & 6.50 & 6.40 & 6.20 & - & 26.90 & 26.00 & 22.30 \\
\hline 22 weeks & - & 6.60 & 6.50 & 6.30 & - & 28.60 & 28.00 & 27.00 \\
\hline 24 weeks & - & 6.70 & 6.60 & 6.40 & - & 31.60 & 31.00 & 30.00 \\
\hline
\end{tabular}

$1=$ Examined samples treated with Bifidobacterial culture

$2=$ Examined samples treated with Potassium sorbate $1.5 \%$

$3=$ Examined samples treated with combination of Bifidobacterial culture and potassium sorbate $1.5 \%$ 
Assiut Vet. Med. J. Vol. 53 No. 112 January 2007

Table 6: icrobiological quality of control and treated samples stored at $-18^{\circ} \mathrm{C}$.

\begin{tabular}{|c|c|c|c|c|c|c|c|c|c|c|c|c|c|c|c|c|}
\hline \multirow[t]{2}{*}{ Time } & \multicolumn{4}{|c|}{$\begin{array}{c}\text { APC } \\
\mathrm{CFU} / \mathrm{g}\end{array}$} & \multicolumn{4}{|c|}{$\begin{array}{c}\text { Enterobacteriaceae count } \\
\mathrm{CFU} / \mathrm{g}\end{array}$} & \multicolumn{4}{|c|}{$\begin{array}{l}\text { Coliforms count } \\
\text { (MPN/g) }\end{array}$} & \multicolumn{4}{|c|}{ Staphylococcus aureus count CFU/g } \\
\hline & Control & 1 & 2 & 3 & Control & 1 & 2 & 3 & Control & 1 & 2 & 3 & Control & 1 & 2 & 3 \\
\hline 0 time & $8 \times 10^{4}$ & $6 \times 10^{4}$ & $4 \times 10^{4}$ & $2 \times 10^{4}$ & $10^{3}$ & $10^{3}$ & $10^{3}$ & $10^{3}$ & 92 & 92 & 92 & 92 & $3 \times 10^{2}$ & $3 \times 10^{2}$ & $3 \times 10^{2}$ & $3 \times 10^{2}$ \\
\hline 2 weeks & $5.8 \times 10^{4}$ & $5.1 \times 10^{4}$ & $3.1 \times 10^{4}$ & $8.8 \times 10^{3}$ & $7.6 \times 10^{2}$ & $5.5 \times 10^{2}$ & $4.5 \times 10^{2}$ & $3.1 \times 10^{2}$ & 76.6 & 70 & 66.6 & 43.6 & $2.7 \times 10^{2}$ & $2.3 \times 10^{2}$ & $2.1 \times 10^{2}$ & $1.6 \times 10^{2}$ \\
\hline 4 weeks & $5.3 \times 10^{4}$ & $4.1 \times 10^{4}$ & $3 \times 10^{4}$ & $6.2 \times 10^{3}$ & $5.2 \times 10^{2}$ & $5 \times 10^{2}$ & $3 \times 10^{2}$ & $2.6 \times 10^{2}$ & 76.6 & 66.6 & 43.6 & 28.6 & $2.5 \times 10^{2}$ & $2.1 \times 10^{2}$ & $2 \times 10^{2}$ & $1.5 \times 10^{2}$ \\
\hline 6 weeks & $4.6 \times 10^{4}$ & $3.8 \times 10^{4}$ & $2.2 \times 10^{4}$ & $2.6 \times 10^{3}$ & $4.3 \times 10^{2}$ & $3.5 \times 10^{2}$ & $2.5 \times 10^{2}$ & $1.7 \times 10^{2}$ & 40 & 31 & 28.6 & 22.3 & $2.3 \times 10^{2}$ & $2 \times 10^{2}$ & $1.7 \times 10^{2}$ & $1.3 \times 10^{2}$ \\
\hline 8 weeks & $3.1 \times 10^{4}$ & $3.1 \times 10^{4}$ & $1.5 \times 10^{4}$ & $1.1 \times 10^{3}$ & $3.3 \times 10^{2}$ & $2.5 \times 10^{2}$ & $1.5 \times 10^{2}$ & $10^{2}$ & 25 & 23.3 & 22.3 & 21.6 & $2.1 \times 10^{2}$ & $1.8 \times 10^{2}$ & $1.5 \times 10^{2}$ & $1.2 \times 10^{2}$ \\
\hline 10 weeks & $1.5 \times 10^{4}$ & $2.5 \times 10^{4}$ & $1.2 \times 10^{4}$ & $10^{3}$ & $1.5 \times 10^{2}$ & $1.3 \times 10^{2}$ & $10^{2}$ & $10^{2}$ & 23 & 22.3 & 21.6 & 14.3 & $2 \times 10^{2}$ & $1.7 \times 10^{2}$ & $1.4 \times 10^{2}$ & $10^{2}$ \\
\hline 12 weeks & $8.3 \times 10^{3}$ & $1.9 \times 10^{4}$ & $0.9 \times 10^{4}$ & $7.6 \times 10^{2}$ & $10^{2}$ & $10^{2}$ & $10^{2}$ & $10^{2}$ & 21.6 & 21 & 11 & 10.3 & $1.8 \times 10^{2}$ & $1.6 \times 10^{2}$ & $1.3 \times 10^{2}$ & $<10^{2}$ \\
\hline 14 weeks & $6.3 \times 10^{3}$ & $9.5 \times 10^{3}$ & $7.6 \times 10^{3}$ & $6.8 \times 10^{2}$ & $10^{2}$ & $10^{2}$ & $10^{2}$ & $<10^{2}$ & 11 & 11 & 9 & 5 & $1.5 \times 10^{2}$ & $1.4 \times 10^{2}$ & $1.2 \times 10^{2}$ & $<10^{2}$ \\
\hline 16 weeks & $7.4 \times 10^{3}$ & $5.6 \times 10^{3}$ & $4.8 \times 10^{3}$ & $4.4 \times 10^{2}$ & $10^{2}$ & $10^{2}$ & $10^{2}$ & $<10^{2}$ & 11 & 9 & 7.6 & 4.6 & $1.6 \times 10^{2}$ & $1.4 \times 10^{2}$ & $10^{2}$ & $<10^{2}$ \\
\hline 18 weeks & $3.5 \times 10^{3}$ & $1.5 \times 10^{3}$ & $1.1 \times 10^{3}$ & $3.5 \times 10^{2}$ & $10^{2}$ & $10^{2}$ & $10^{2}$ & $<10^{2}$ & 9 & 7.6 & 5 & 2.6 & $1.3 \times 10^{2}$ & $10^{2}$ & $<10^{2}$ & $<10^{2}$ \\
\hline 20 weeks & $2.5 \times 10^{3}$ & $1.3 \times 10^{3}$ & $1.3 \times 10^{3}$ & $2.9 \times 10^{2}$ & $10^{2}$ & $10^{2}$ & $<10^{2}$ & $<10^{2}$ & $<3$ & $<3$ & $<3$ & $<3$ & $<10^{2}$ & $<10^{2}$ & $<10^{2}$ & $<10^{2}$ \\
\hline 22 weeks & $1.5 \times 10^{3}$ & $10^{3}$ & $10^{3}$ & $2.9 \times 10^{2}$ & $<10^{2}$ & $<10^{2}$ & $<10^{2}$ & $<10^{2}$ & $<3$ & $<3$ & $<3$ & $<3$ & $<10^{2}$ & $<10^{2}$ & $<10^{2}$ & $<10^{2}$ \\
\hline 24 weeks & $10^{3}$ & $7.2 \times 10^{2}$ & $5.2 \times 10^{2}$ & $2.1 \times 10^{2}$ & $<10^{2}$ & $<10^{2}$ & $<10^{2}$ & $10^{2}$ & $<3$ & $<3$ & $<3$ & $<3$ & $<10^{2}$ & $<10^{2}$ & $<10^{2}$ & $<10^{2}$ \\
\hline
\end{tabular}

$1=$ Examined samples treated with Bifidobacterial culture

2= Examined samples treated with Potassium sorbate $1.5 \%$

$3=$ Examined samples treated with combination of Bifidobacterial culture and potassium sorbate $1.5 \%$ 
Assiut Vet. Med. J. Vol. 53 No. 112 January 2007 
Assiut Vet. Med. J. Vol. 53 No. 112 January 2007 


\section{DISCUSSION}

\section{Chilled fish fillets at $5^{\circ} \mathrm{C} \pm 1$ :}

\section{I- Sensory evaluation:}

Results in Table (1) show that fillets retained good quality up to the third day of storage at $5^{\circ} \mathrm{C}$ in untreated sample; gradual decline in sensory quality has been noticed. Fillets showed good quality for the $4^{\text {th }}$ day and just acceptable till the $6^{\text {th }}$ day. These results were in agreement with that recorded by Ravn et al., (1988); Laskshmanan and Gopakumar, (1996); Badr et al., (2001) and El-Mossalami et al., (2004).

Samples treated with $1.5 \%$ potassium sorbate and Bifidobacterial culture alone showed higher score till the $6^{\text {th }}$ day than control one (Chang and James, 1994; Farid et al., 1998; Badr et al., 2001; Kim et al., 1995a). While those samples treated with combination of potassium sorbate and Bifidobacterial culture were quite close in flavour, odor and appearance to fresh controls with higher scores over a period of $14^{\text {th }}$ day's storage. These results were in harmony with that recorded by Chang and James (1994) and Mosffer et al., (1999).

\section{II- Chemical parameters of chilled treated fish fillets:}

\section{1- pH-Value:}

Table (2) and Figure (1) show a decrease in $\mathrm{pH}$ values in all treated samples during storage, compared with the control sample. Maximum decrease in $\mathrm{pH}$ values was observed in samples treated with $1.5 \%$ potassium sorbate and Bifidobacterial culture mixture. Decrease in $\mathrm{pH}$ values may be due to the microbial enzyme activity and autolysis producing organic acid or treatment of fillets with potassium sorbate alone or in mixture of Bifidobacterial culture. These results agree with those reported by Mendonca et al., 1989; Kim et al., 1995a; Zhuang et al., 1996; Marshall and Jindal, 1997; Badr et al., 2001; Mosffer et al., 1999).

\section{2- Total Volatile Basic Nitrogen (TVBN) (mg/100gm):}

Results represented in Table (2) and Figure (2) indicate the formation of total volatile basic nitrogen was affected by all treatments than the control one throughout storage, a gradual increase occurred. The lowest value of TVBN occurred in samples treated with combination of $1.5 \%$ potassium sorbate and Bifidobacterial culture, while maximum TVBN was found in control samples followed by samples treated with Bifidobacterial culture, $1.5 \%$ potassium sorbate and combination of $1.5 \%$ potassium sorbate and Bifidobacterial culture. 
Connel (1990) reported that the content of TVBN is a useful indicator of freshness of lean fish and suggested 30-40 mgN/100g. However, the increment in TVBN during storage in ice could be the result of decomposition and degradation of nitrogen substance which may be due to the activity of microorganisms. These results are in line with those obtained by Woyewoda and Bilgh (1986); Khuntia et al., (1993); Badr et al., (2001).

\section{III- Microbiological examination of chilled treated fish fillets:}

Results in Table (3) and Figure (3) indicate maximum APC was observed in control samples followed by the fish fillets treated with Bifidobacterial culture, potassium sorbate $1.5 \%$ alone and combination of potassium sorbate $1.5 \%$ and Bifidobacterial culture respectively.

It is worthily to mention that the decrease of APC in those treated with $1.5 \%$ potassium sorbate may be due to its bacteriostatic effect (Buncic et al., 1995; Badr et al., 2001) and extend shelf life of fish during storage at $5^{\circ} \mathrm{C} \pm 1$.

APC was higher in control and treated samples with Bifidobacterial culture and $1.5 \%$ potassium sorbate during storage for 12 days at $5^{\circ} \mathrm{C} \pm 1$. These results coincide with those given by Mendonca et al., (1989a); Khuntia et al., (1993); Buncic et al., (1995); Kim et al., (1995a); Zhuang et al., (1996); Marshal and Jindal, (1997); Badr et al., (2001).

Chang et al., (1995) reported that APC in refrigerated $\left(4^{\circ} \mathrm{C}\right)$ Tilapia fillets were directly affected by potassium sorbate.

With respect to those treated with Bifidobacterial culture, the observed decrease was due to the antimicrobial property of Bifidobacterial culture which produce lactic, acetic acid, hydrogen peroxide and possibility unknown compounds.

APC of fillets with Bifidobacterial culture alone rapidly increased after 3 days of storage, but fillets were not considered spoiled by the sensory panel until after 6 days.

Aerobic food spoilage organisms in refrigerated food can reduce shelf life and microbiological quality (Reddy et al., 1970; Shewan, 1971; Gilliland and Specks, 1975; Post et al., 1985; Ingham, 1989; Berry et al., 1991). The combination of lactic acid producing bacteria (BIfidobacterial culture) and food additives could be considered as a food preservative to repress growth of such microorganisms (Reddy et al., 1970; Gilliland and Ewell, 1983; Lindgren and Dobrogoze, 1990).

Table (3) revealed that APC in untreated fish rapidly increased for 14 days. While counts from a treatment with combination of 
potassium sorbate and lactic acid culture caused a significant decrease during the 6 days of storage at $\mathrm{pH}$ 5.8. However, undesirable microorganisms grew visibly after 9 days. This was in agreement of Kim and Hearnberger (1994) and Chang et al., (1995) who stated that combination of Bifidobacteria with potassium sorbate efficiency inhibited growth of Gram negative bacteria in refrigerated catfish fillets.

From the achieved results in Table (3) and Figure (4), Enterobacteriaceae count at zero time were $10^{3}$ increased after 2, 4, 6, 8, 10,12 and 14 days of storage at $5^{\circ} \mathrm{C}$, which become $3.9 \times 10^{5}$ (signs of rejection was noticeable), Coliforms could be detected with slight increase from 92 till reached $210 \mathrm{CFU} / \mathrm{ml}$ at the end of storage period (Table 3 and Figure 5). E. coli failed to be detected in control and treated samples. These findings were in agreement with those reported by Rose (1968); Abd Almenom (1986) and Daoud and El-Mossalami (2002) who stated that Gram negative bacteria are more susceptible to cold. There is a marked decrease in total bacterial, Enterobacteriaceae, Coliforms and Staphylococcal counts in samples treated with $1.5 \%$ potassium sorbate than other control samples during storage at $5^{\circ} \mathrm{C}$ for 18 days. These results coincide with those given by Mendonca et al., (1989b); Khuntia et al., (1993); Buncic et al., (1995); Kim et al., (1995b); Zhuang et al., (1996); Marshal Jindal (1997) and Badr et al., (2001).

It is worthily, to mention that in samples treated with Bifidobacterial culture, there was a marked decrease in all bacterial counts (plate count, Enterobacteriaceae, Coliforms and Staphylococcal count), as Bifidobacterial culture having a pronounced inhibiting effect on Gram negative and Gram positive bacteria (Reddy et al., 1984; Schaack and Marth, 1988; Wijsman et al., 1989; Harris et al., 1991; Okereke and Montville, 1991; Kebbary, 1995 Badawi and El-Sonbaty, 1997; Abou-Dawood, 2002).

Bifidobacteria may control food spoilage bacteria and foodborn pathogens through production of lactic and acetic acids as well as other antibiotic substances (Laroia and Martin, 1990; Modler et al., 1990; Hughes and Hoover 1991; Ray 1992).

These results agree with Martin and Chou (1992); Biavati et al., (1992) and Mehanna et al., (2002) who observed that $88 \%$ of Bifidobacterial strains tested decrease their viability after 7 days of storage under acidic conditions (skim milk at $\mathrm{pH} 4.0$ ) and less than $10 \%$ survived after 15 days. Others recorded a decrease in 0.5 log cycles after 4months at refrigeration (Robinson, 1990; Gomes et al., 1995; Mehanna et al., 2002). 
Blanchette et al., (1996) and Effat (2002) found that the presence of lactic and acetic acids inhibit the growth of Bifidobacteria after 4 weeks of refrigeration storage.

A previous report on treated fillets with potassium sorbate or combined with Bifidobacteria attributed antimicrobial effects primarily to potassium sorbate (Kim and Hearnsbergers 1994).

From our results, an additive interaction occurred when Bifidobacteria were combined with potassium sorbate, the initial $\mathrm{pH}$ values of fillets treated with $1.5 \%$ potassium sorbate and Bifidobacteria, either alone or combined were 5.7, and 5.6 Units, lower than untreated control fillets $\mathrm{pH}$ (6.0). Hence, inhibitory effect results in our study were likely due to changes in $\mathrm{pH}$ and to the specific action of potassium sorbate. These results were in agreement of Chang et al., (1995) and disagreed with Kim and Hearbsberger (1992b) who stated that treated catfish fillets with organic acid didn't necessarily have lower $\mathrm{pH}$ than controls, but remained inhibitory to growth of aerobes (Kim and Hearnsberger, 1994). Quality and safety of refrigerated foods have been enhanced by preventing growth or destroying aerobic spoilage bacteria and foodborne pathogens during storage and handling using food additives and biopereservatives (Gilliland and Ewell, 1983; Lindgren and Dobrogosz, 1989; Kim and Hearnsberger, 1994). However, biopreservatives such as lactic acid bacteria suppress aerobic bacteria that cause food spoilage (Raccach and Baker, 1978; Gilliland and Ewell, 1983; Schaack and Marth, 1988).

\section{Frozen fillets at $-\mathbf{1 8}^{\circ} \mathrm{C} \pm 1$ :}

\section{I- Sensory evaluation:}

The data obtained during experiment in Table (4) showed that organoleptic scores had occurred in frozen samples during the successive weeks of storage at home freezer $\left(-18^{\circ} \mathrm{C}\right)$ where it reached a suggestive limit of 3 at the $14^{\text {th }}$ week of storage.

The organoleptic scores of treated fillets with Bifidobacterial culture decreased gradually to suggestive limits 2.9 at the $22^{\text {nd }}$ week of storage at home freezer $\left(-18^{\circ} \mathrm{C}\right)$, while reached 2.3 at the end of experiment $24^{\text {th }}$ week of storage.

The organoleptic scores of treated Tilapia fillets with $1.5 \%$ potassium sorbate gradually decreased till reached a suggestive limits 3.0 at the $22^{\text {nd }}$ week of storage at home freezer, while scores of 2.5 at the $24^{\text {th }}$ week of storage (end of the experiment).

Within each treatment, acceptability decreased with increasing storage time with the exception of combination of $1.5 \%$ potassium 
sorbate and Bifidobacterial culture treatment was the best in maintaining the acceptability till the end of storage period ( 24 weeks). These values agreed well with the microbiological shelf life. These results agreed with those of Mocking and Machava (1986); Benner et al., (1994) and Kim et al., (1995b).

The difference in keeping quality time is due to the nature of the initial microflora present on fish at the time of capture as well as the effect of freezing on the microbial load. Moreover, the use of $1.5 \%$ potassium sorbate, Bifidobacterial culture and/or combination of them on treated samples had antimicrobial effect on the surface contaminations of fish samples. This held the view reported by Jadhav and Magar (1970); Choi et al., (1986); Joseph et al., (1989) and CanoMunoz (1991).

\section{II- Chemical parameters of frozen treated fish fillets: \\ 1- pH-Value:}

The data obtained during this investigation recorded in Table (5) and Figure (7) regarding the $\mathrm{pH}$ values of the fresh samples was 5.9. Gradual increase in the $\mathrm{pH}$ values of frozen samples occurred during successive weeks of storage at home freezer $\left(-18^{\circ} \mathrm{C}\right)$, where it reached a limit of 6.23 at the $10^{\text {th }}$ week and 6.7 at the $18^{\text {th }}$ week.

The mean $\mathrm{pH}$ value of Tilapia fish fillets samples treated with Bifidobacterial culture subjected to a slight decrease (5.6) immediately after treatment then showed a gradual increase where it arrived a level of $6.1,6.6$ and 6.7 at the $12^{\text {th }}, 22$ nd and $24^{\text {th }}$ weeks of storage respectively at home freezer $\left(-18^{\circ} \mathrm{C}\right)$.

The mean $\mathrm{pH}$ values of Tilapia fillets samples treated by $1.5 \%$ potassium sorbate (Table 5 and Figure 7) subjected to a slight decrease (5.6) immediately after treatment, then showed a gradual increase where it arrived a level of $6.0,6.5$, and 6.6 at $12^{\text {th }}, 22^{\text {nd }}$ and $24^{\text {th }}$ weeks of storage respectively at home freezer $\left(-18^{\circ} \mathrm{C}\right)$.

It is of importance to recognize that the maximum $\mathrm{pH}$ limit given by EOS (1991) had been encountered in the frozen samples stored for $10-12$ weeks at $-18^{\circ} \mathrm{C}$ is 6.2 . On the other hand, such limit had been observed at 10,14, 16, and 20 weeks of storage at home freezer for control, treated samples with Bifidobacterial culture, $1.5 \%$ potassium sorbate and combination of them respectively at the same temperature.

The present data reported here, indicated that maximum $\mathrm{pH}$ limit stipulated by EOS (1991) has been recognized in the frozen untreated fillets samples after 10 weeks of storage at home freezer $\left(-18^{\circ} \mathrm{C}\right)$ whereas treated samples showed such limit within $14^{\text {th }}, 16^{\text {th }}$ and $24^{\text {th }}$ week with 
Bifidobacterial culture, potassium sorbate, or mixture of $1.5 \%$ potassium sorbate and Bifidobacterial culture of storage at the same degree of temperature.

In this regard, Eitenmiller et al., (1982) considered that, the $\mathrm{pH}$ value was not a good diagnostic indicator for the quality of fish as well as unsatisfactory to indicate early stages of spoilage in frozen fishes.

Meanwhile, Galli et al., (1993) held the opinion that gradually increased $\mathrm{pH}$ values of fishes during freeze storage indicated bacterial growth and possible spoilage of fish. A pH value of more than 6.6 had been reported for spoiled fish and could be attributed to the decomposition of fish protein to the level of amino acids followed by their decarboxylation and deamination and production of volatile basic compounds such as ammonia.

From the above mentioned discussion, it could be safely concluded that the treatment of fish by 1.5 potassium sorbate and/or Bifidobacterial culture were the best treatment lead to extending the keeping quality of frozen fishes comparison with the untreated frozen fishes.

\section{2- Total Volatile Basic Nitrogen (TVBN) (mg/100gm):}

It is evident from the results recorded in Table (5) and Figure (8) that the estimated TVBN values reached $32.92 \mathrm{mg} / 100 \mathrm{gm}$ of the examined control samples at $16^{\text {th }}$ week of storage whereas in treated samples they were $31.6,31$ and $30 \mathrm{mg} / 100 \mathrm{gm}$ of samples treated with Bifidobacterial culture, potassium sorbate $1.5 \%$ and combination of both at 24 week of storage respectively.

Meanwhile, EOS (1991) stipulated the maximum limit of TVBN for frozen fish to be not more than $30 \mathrm{mg} / 100 \mathrm{~g}$ of fish flesh. The gradual increase of TVBN in present data may be attributed to several volatile odour bearing compounds like the volatile basic nitrogenous compounds produced in fish as a result of bacterial spoilage which are not normally found in live muscles. The increase TVBN is logarithmically parallel with microbial growth; therefore it may provide useful data for the evaluation of fish freshness. This substitutes the finding reported by Botta et al., (1984).

In this respect, Ehira et al., (1984) and Person (1984) also stated that the fish at the point of incipient deterioration contain $30 \mathrm{mg}$ of TVBN per $100 \mathrm{~g}$ fish.

Such findings spot light on the efficiency of treatment with a mixture of $1.5 \%$ of potassium sorbate and bifisobacterial culture in 
extending the keeping quality of treated fish up to 24 weeks in comparison to untreated samples.

\section{III- Microbiological examination of frozen treated fish fillets:}

From the results obtained in Table (6) and Figure (9), it is evident that the minimum aerobic plate counts of experimentally control frozen fish fillets at zero time was $8 \times 10^{4} \mathrm{CFU} / \mathrm{g}$. The storage of such fish at home freezer for $18^{\text {th }}$ weeks caused slight decrease in aerobic plate count during the first 4 weeks constituting $3.5 \times 10^{3} \mathrm{CFU} / \mathrm{g}$.

Nevertheless, treated fish fillets with Bifidobacterial culture, the aerobic plate counts decreased reaching $6 \times 10^{4}$ at zero time of the experiment, followed by the decrease of such counts to $7.4 \times 10^{2} \mathrm{CFU} / \mathrm{g}$ after 24 weeks of storage.

Concerning the treatments of fish fillets with potassium sorbate, the aerobic plate counts decreased reaching $4 \times 10^{4} \mathrm{CFU} / \mathrm{g}$ at zero time of experiment followed by the decrease of such counts to $5.2 \times 10^{2} \mathrm{CFU} / \mathrm{g}$, after 24 weeks of storage at home freezer.

In comparison of the aerobic plate counts of experimentally frozen fish with $1.5 \%$ potassium sorbate or Bifidobacterial culture at home freezer $\left(-18^{\circ} \mathrm{C}\right)$, the reduction in total bacterial numbers during the first 4 weeks of freezing storage period could be attributed to the disappearance of mesophilic organisms that could not adapt to the cold environment. At this point psychrotrophic spoilage flora had been established and began to multiply, as well as the total plate count decreased rapidly until signs of spoilage appear (18 weeks). This substitutes the finding reported by Acuff et al., (1984). In this respect, Frazier (1967) reported that, freezing kills some but not all microorganisms present in fish where psychrotrophs can survive freezing and are ready to grow on thawing.

On the other hand, ESO (1991) stated that, the permissible limit for the total bacterial count for frozen fish was no more than $10^{6} \mathrm{CFU} / \mathrm{g}$ fish muscles. Comparatively, it is obvious that the incipient spoilage in fish fillets took place after 18 weeks as well as, the incipient deterioration in frozen fish fillets treated with potassium sorbate, Bifidobacterial culture occur after 24 weeks alone or in mixture.

The microbial activity is one of the main caused of quality deterioration of fish, so the spoilage pattern of fish depends upon the initial bacterial count, in addition to those acquired during handling and storage (Cobb and Vanderzant, 1971). However, Thatcher and Clark (1978) stated that, the high viable counts of frozen fish indicates 
contamination of materials from unsatisfactory sanitation during handling, processing as well as inadequate chilling and/or freezing.

From the present data it could be concluded that, the extended shelf life of treated frozen fillets with $1.5 \%$ potassium sorbate and Bifidobacterial culture had higher inhibitory effect that each of them, these results were in harmony with Harris et al., (1991); Okereke and Montville, (1991) and Chang et al., (1995) who stated that combination of organic acids and Bifidobacterial culture was effective in suppressing aerobic spoilage bacteria on catfish fillets and should be considered as a potential method for shelf life extension.

The Enterobacteriaceae counts in experimentally control frozen fillets at zero time was $10^{3} \mathrm{CFU} / \mathrm{g}$. This was followed by a gradual decrease in the Enterobacteriaceae counts to $10^{2} \mathrm{CFU} / \mathrm{g}$ after 12 weeks storage (Table 6 and Figure 10)

With respect to Enterobacteriaceae counts in experimentally treated fish with Bifidobacterial culture a gradual decrease was observed till reached $10^{2} \mathrm{CFU} / \mathrm{g}$ at 22 weeks till 24 weeks (end of the experiment). These results agree with that recorded by Kebary (1995) and Korshunove et al., (1999).

Dealing with the treated fillets with $1.5 \%$ potassium sorbate, the Enterobacteriaceae counts decreased to $10^{2} \mathrm{CFU} / \mathrm{g}$ from 10 weeks till the end of the experiment ( 24 weeks). These results agree with that reported by Buncic et al., (1995) and Badr et al., (2001).

It is concluded, that the data present revealed the noticeable significant decrease of Enterobacteriaceae count till reach $<10^{2}$ at the end of experiment.

The counts of Enterobacteriaceae may have potential indicator for not only of health hazard but also as an indicator of spoilage (Gorczyca et al., 1985). Members of family Enterobacteriaceae are potential public health importance as it causes diseases for humans during lowering of their resistance. Also this group contains most members of food poisoning microorganisms (Edwards and Ewing 1972; Collins 1984).

Freezing kills a proportion (usually 60-90\% of the Enterobacteriaceae bacteria present) and cold storage results in a further less dramatic and gradual decrease in their numbers, in addition other organisms are injured (Weber and Schmidt, 1989). 
From the present data, it could be concluded that the treatment of fish fillets with $1.5 \%$ potassium sorbate and Bifidobacterial culture lead to lower in Enterobacteriaceae count to a great extent. As the antimicrobial effect of organic acids (potassium sorbate) could be enhanced by the combination with lactic acid bacteria producing natural organic acids as lactic and acetic acid (El-Shenawy and Marth (1988); Chang and James 1994).

Korshounov et al., (1999) stated that Bifidobacterial strains capable of exhibiting the growth of all indicator bacterial strains (Escherichia coli, Klebsiella, Staphylococcus aureus, Enterococcus faecalis, Pseudomnas aeruginosa).

The given results in Table (6) and Figure (11) showed that the MPN of coliforms in frozen untreated Tilapia fillets during frozen storage at home freezer at zero time were $92 \mathrm{CFU} / \mathrm{ml}$. The count gradually decreased and correlated the lowest levels after 18 weeks (9 $\mathrm{CFU} / \mathrm{ml}$ ). In general, the MPN of coliforms decreased gradually till reached $<3 \mathrm{CFU} / \mathrm{ml}$ in all treated samples at the end of storage time (end of experiment) at home freezer $\left(-18^{\circ} \mathrm{C}\right)$. Nearly similar results were obtained by Wu and Chen, (1980); El-Sayed (1991) and Yehia (1996). But higher numbers were obtained by Abdel-Galil et al., (1988); Mahmoud (1990) and Mahmoud (1994).

Comparatively, the obtained results of the experimentally frozen fish and treated frozen fish were within the permissible limits (100 colonies/ml) recommended by ESO (1991) for frozen fishes. Used of the coliforms count as an index of pollution in frozen food has been criticized because of the susceptibility of this group of microorganisms to freezing injury resulting in gradual disappearance in their numbers in frozen food during continued storage (Licciardello and Hill, 1978). Presence of coliforms in frozen fish in the present study may be attributed to neglected sanitary measures during production and handling. This agrees with that reported by (Licciardello and Hill, 1978). In this respect, Farouk (1989); El-Sayed (1991); Seback (1998) stated that the presence of coliforms in fish serves as an index of sanitation and proper handling conditions.

E. coli could not be detected in this study. The present results were coincide with that of Raj Liston, (1963); Joseph et al., (1989) and Soliman and Shalaby (2001). They reported that E. coli was absent in fish after freezing. While samples treated with $1.5 \%$ potassium sorbate, Bifidobacterial culture alone or in combination there is noticeable decrease in coliforms count was due to the effect of bacteriocidal effect 
of potassium sorbate (Badr et al., 2001) and the antimicrobial substances and acid production of Bifidobacterial culture (Badawi and El-Sonbaty, 1997; Nour and Abosrea 2005).

From the achieved results in Table (6) and Figure (12), coagulase-positive Staphylococcus aureus in Tilapia fillets were present in count of $3 \times 10^{2} \mathrm{CFU} / \mathrm{g}$ at zero time of control samples. Similar findings were obtained by Mohamed (1990); Saad et al., (1991) and ElShater (1999). The frequent contamination on examined fish samples with Staphylococcus aureus is undoubted imparted from skin, mouth and nose of fish handlers (Polledo et al., 1986), beside dirty utensils (Banwarl, 1989). From the recorded results, Staphylococcus aureus counts decreased by freezing till reach $<10^{2} \mathrm{CFU} / \mathrm{g}$ at the $18^{\text {th }}$ week of storage. It is evident that the freezing resulted in loss of Staphylococcus aureus viability as manifested by the drop of viable counts. This observation is consistent with that finding of Raj Liston (1963) who found that a temperature of $-18^{\circ} \mathrm{C}$ for 393 days decreased the number of Staphylococcus aureus contaminating sea food by ten folds. In this respect Jackson (1974) reported that certain function such as multiplication and cell division could obviously not occur below the minimum growth temperature. Moreover, Ingram and Mamckery (1967) recorded that during the process of freezing many organisms are mechanically crushed or injured by extracellular ice crystals. Similar findings had been recorded by Niazi et al., (1988) who recorded that the exposure of toxigenic Staphylococcus aureus to freezing storage resulted in gradual loss in its viability by time.

Regarding the effect of $1.5 \%$ potassium sorbate and Bifidobacterial culture on fish fillets stored at the same temperature, the viable counts at Zero time was $3 \times 10^{2} \mathrm{CFU} / \mathrm{g}$, recording noticeable decrease in its count reaching $<10^{2}$ at the $10^{\text {th }}$ week of storage. These results are in agreement of Niazi et al., (1988) who reported that after 24 weeks of storage no viable organisms could be detected in minced meat. Joseph et al., (1989) reported that coagulase positive Staphylococci were absent in frozen fish after freezing.

Concerning, Staphylococcal counts in fish fillets treated with a mixture of Bifidobacterial culture and $1.5 \%$ potassium sorbate, there is a recorded decrease at zero time which was $3 \times 10^{2} \mathrm{CFU} / \mathrm{g}$ with a remarkable decrease till reach $<10^{2}$ at the beginning of $18^{\text {th }}$ week of storage. This reduction was due to the bacteriocidal effects of potassium sorbate and the effect of freezing with addition of the antimicrobial activity associated with Bifidobacterium (Anand et al., (1984); Lindgren 
and Dobrogosz (1990); Kurmann and Rasic (1991); Kebary (1995); Badawi, (1997); Korshunov et al., (1999); Ahmed et al., (2002); Vazquez et al., (2005).

The combination of potassium sorbate $1.5 \%$ and Bifidobacterial culture was shown to be effective on improving sensory, chemical, microbiological quality and increasing the shelf life of Bolti fish fillets during the storage period of both samples stored at $4^{\circ} \mathrm{C}$ or those samples stored at $-18^{\circ} \mathrm{C}$.

\section{REFERENCES}

Abd Almenom, K.M. (1986): Microbial association in cool stored beef. M. V. Sc. Thesis, Fac. Vet. Med. Cairo Univ.

Abdel-Galil, Y.; El-Daly, E. and Mansour, N. (1988): Enteric organisms prevalent in market fish with special reference to E. coli. Bull. High Inst. Publ., Hlth. 18: 1123-1129.

Abou-Dawood, S.A.I. (2002): Survival of none encapsulated and encapsulated Bifidobacterium bifidum in probiotic kareish cheese. Egypt. J. Dairy Sci., 30: 43-52.

Acuff, G.; Izat, A.l. and Finne, G. (1984): Microbial flora of reared Tilapia (Tilapia aura) held on ice. J. Food. Prot. 47: 778-780.

Ahmed, Azza, H.; Aidea, Hoda, A.M.; Sherif, Mona, M.A. and Wehab, Hala, H. (2002): Effects of Bifidobacteria on some pathogenic bacteria in yoghurt and on serum cholesterol level in rats. $\mathrm{J}$. Egypt. Vet. Med. Assoc., 62 (66): 43-56.

Anand, S.K.; Srinivasan, R.A. and Rao, L.K. (1984): Antimicrobial activity associated with Bifidobacterium. 1. Cult. Dairy Prod. J., 11: 6-7.

AOAC, (1990): Association of Official Analytic Chemists. Official Methods of Analysis. $15^{\text {th }}$ Ed.

APHA, (1992): Compendium of Methods for the Microbiological Examination of Foods. $3^{\text {rd }}$ Ed. Edwards Brothers, Washington.

Badawi, R.M. and El-Sonbaty, A.H. (1997): Viability of Staphylococcus aureus and Escherichia coli in Zabady and with Bifidobacteria. Egypt. J. Dairy Sci., 25: 217.

Badr, F.H.; Ez-El-Rigal, A.I. and Abou-El-Matti, S.M. (2001): Effect of sodium monophosphate and potassium sorbate on the quality of common carp fish fillets during chilling storage. Egypt. J. Food Sci., 29: 139-151. 
Banwarl, G.J. (1989): Basic Food Microbiology. $2^{\text {nd }}$ Ed. An AviBook, Published by Van Nostrand Reinhold, New York.

Benner, R.A.; MiGet; Finne, G. and Acuff, G.R. (1994): Lactic acid/ Melanosis inhibitors to improve shelf life of Brown Shrimp (Penaeus aztecus). J. Food Sci., 59: 242-245.

Berry, E.D.; Hutkins, R.W. and Mandigo, R.W. (1991): The use of bacteriocin-producing Pedococcus acidlacticici to control postprocessing Listeria monocytogenes contamination of frankfurters. J. Food Prot. 54: 681-388.

Beuchat, L.R.; Shewfelt, A.L. and Worthington, R.E. (1975): Catfish: Composition, Utilization and Storage Stability. Research Bull. 171, Dept. of Food Sci. Georgia Experiment Station, Griffin, GA.

Biavati, B.; Sozzi, T.; Mattareli, P. and Trovatelli, D. (1992): Survival of Bifidobacteria from human habitat in acidified milk. Microbiologica, 15: 197.

Blanchette, L.; Roy, D.; Belanger, G. and Gauthier, F.S. (1996): Production of cottage cheese using dressing fermented Bifidobacteria. J. Dairy Sci., 79:81.

Botta, J.R.; Lauder, J.T. and Jewer, M.A. (1984): Effect of methodology on Total Volatile Basic Nitrogen (TVBN) determination as an index of quality of Atlantic cod (Gadus morhua). J. Food Sci., 49: 734-736.

Buncic, S.; Fitzgerald, C.M.; Bell, R.G. and Hudson, J.A. (1995): Individual and combined listericidal effects of sodium lactate, potassium sorbate, nisin and curing salts at refrigeration temperature. J. Food Safety, 15: 247.

Cano-Munoz, G. (1991): Manual on meat cold store operation and management. FAO. Anim. Product. HLTH Paper, No. 92.

Chang, R.K. and James, O.H. (1994): Gram negative bacteria inhibition by lactic acid culture and food preservative on cat fish fillets during refrigerated storage. J. Food Sci., 59: 513-515.

Chang, R.K.; James, O.H.; Amy, P.; Charles, H.W. and Douglas, L.M. (1995): Sodium acetated and Bifidobacteria increase shelf-life of refrigerated Catfish fillets. J. Food Sci., 60 (1): 25-27.

Choi, J.D.; Chang, D.S. and Kim, Y.M. (1986): Survival of sanitary bacteria inoculated in fish muscle homogenates during freezing and frozen storage. Bull. Korean. Fish. Soc. 19 (4): 356-362. 
Cobb, B.F. and Vanderzant, C. (1971): Biochemical changes in shrimp inoculated with Pseudomonas, Bacillus and Coryne form bacterium. J. Milk Food Technol., 34: 533-540.

Collins, C.H. (1984): Microbial Methods. $5^{\text {th }}$ Microbiology Laboratory Manual. British Library, Butterworth Inc. Co.

Connel, J.J. (1990): Control of Fish Quality. Published by Fishing News Books. A division of Black Well Scientific Publication, Cambridge, UK.

Daoud Jehan, R. Daoud and El-Mossalami, M.K. (2002): Chemical and bacteriological changes in cold stored Gamma irradiated fish fillets. J. Egypt. Med. Assoc., 62 (6a): 265-276.

Edwards, P.R. and Ewing, W.H. (1972): Identification of Enterobacteriaceae. $3^{\text {rd }}$ Ed. Burger's Publ. Minneapolis.

Effat, B.A. (2002): Effect of using Lactobacillus reuteri with other probiotic cultures on quality of Dimiati cheese. Minufiya J. Agric. Res., 22: 445.

Ehira, S.; Uchiyama, H. and Kakuda, K. (1984): Partial freezing as a method for retaining the freshness of Sardine: Enzymatic and bacterial freshness in stored samples. Bull. Tokai Reg. Fish. Res. Lab. 114: 103-109.

Eitenmiller, R.R.; Orr, J.H. and Wallis, W.N. (1982): Histamine formation in microbiological and biochemical conditions. pp. 39-50. In R.E. Martin ed., Chemistry and biochemistry of marine food products, AVI Publishing Co., Westport, Co.

El-Mossalami, M.K.; Kassem Gehan, M. and Attallah, O.A. (2004):

Quality changes of some ice-stored aquacultured fish. J. Egypt. Vet. Med. Assoc., 64: 81-91.

El-Sayed, M.F. (1991): Comparative studies on the keeping quality of some Nile and farm fishes. M.V.Sc. Thesis, Fac. Vet. Med. Alex. Univ.

El-Shater, M.A. (1999): Fish fillets. Quality investigation in the Egyptian market. Vet. Med. Ass. J., 59 (5): 1535-1547.

El-Shenawy, M.A. and Marth, E.H. (1988): Inhibition and inactivation of Listeria monocytogenes by sorbic acid. J. Food. Prot., 51: 842847.

EOS (1991): Egyptian Organization for Standardization and Quality Control of frozen fish (889-1991) U. D. C. 621.

FAO (1980): Food and Agriculture Organization of United Nation. Manual of Food Quality Control. United Nation, Rom. 
Farid, M.A.; Bal'A and Douglas, L.M. (1998): Organic acid dipping of cat fish fillets: Effect on color, microbial load and Listeria monocytogenes. J. Food Prot., 61 (11): 1470-1474.

Farouk, M. (1989): Microbiological evaluation of some fishes in rural markets. M. V. Sc. Thesis, Fac. Vet. Med. Alex. Univ.

Frazier, W.C. (1967): Food Microbiology. $2^{\text {nd }}$ Ed. Graw Hill, Publ. Co. N.Y.

Galli, A.L.; Franzetti, L.; Carelli, S.; Piergiovanni, L. and Fava, P. (1993): Microbiological quality and shelf life of chilled cod fillets in vacuum-skin and modified atmosphere packaging. Pack. Technol. Sci., 6: 147-157.

Gilliland, S.E. and Ewell, H.R. (1983): Influence of combinations Lactobacillus lactis and potassium sorbate on growth of psychrotrophs in raw milk. J. Dairy Sci., 66: 974.

Gilliland, S.E. and Speck, M.L. (1975): Inhibition of psychrotrophic bacteria, Lactobacillus and pediococci in nonfermented refrigerated foods. J. Food Sci., 40: 703-707.

Godavari, B.S.; Khabade, V.S. and Parkash, V. (1987): Effect of freezing and sodium citrate treatment on the associationdissociation of proteins from shrimp (Parapenaeopis stylifera). J. Food Sci., 24: 243-246.

Gomes, A.M.P.; Malcata, X.F.; Flaver, A.M.F. and Grande, J.H. (1995): Incorporation and survival of Bifidobacterium species $\mathrm{BO}$ and Lactobacillus acidophilus strain $\mathrm{Ki}$ in cheese product. Neth. Milk and Dairy J. 49: 71.

Gorczyca, E.M.; Anggawati, A. and Putro, S. (1985): Microbiological quality of retail "Wet" fish in Jakarta. FAO Fish Report. No. 317: 191-196.

Harris, L.J.; Fleming, H.P. and Klaenhammer, T.R. (1991): Sensitivity and resistance of Listeria monocytogenes ATCC 19115, Scott, A and UAL 500 to nisin. J. Food Prot., 54: 836-841.

Hughes, D.B. and Hoover, D.G. (1991): Bifidobacteria and their potential for use in America dairy products. Food Technol., 45 (4): 74-83.

Ingham, S.C. (1989): Lactic acid dipping for inhibiting microbial spoilage of refrigerated Catfish fillet pecies. J. Food. Qual. 12: 433-443.

Ingram, M. and Mamckery, B.M. (1967): In: Inhibition and Inactivation of Vegetative Microbes, P.111. Ed. by F. A. Skanner and W. B. Hugo, Academic Press, London. 
Jackson, H. (1974): Loss of viability and metabolic injury of Staphylococcus aureus resulting from storage at $5^{\circ} \mathrm{C}$. J. Appl. Bacteriol. 37: 59-64.

Jadhav, M.G. and Magar, N.G. (1970): Preservation of fish by freezing and glazing: 1- Bacteriology of fresh frozen and glazed fish. Fish Technol., 7: 86-90.

Joseph, A.C.; Surendan, P.K. and Perigreen, S. (1989): Effect of delayed freezing on the quality and shelf-life of Kalawa (Epinephelus species). Fishery-Technol., 26 (2): 107-110.

Joseph, A.C.; Surendran, P.K. and Perigreen, P.A. (1989): Delayed freezing on the quality and shelf life of Kalawa (Epinephelus species). Fish Technol., Soc. Fish. Technol., COC HIN. 26: 107-110.

Kebary, K.M.K. (1995): Production, partial purification and stability of antimicrobial substances. D. I. Egypt. Dairy Sci., 23: 151.

Khuntia, B.K.; Srikar, L.N.; Reddy, L.N. and Srinivasa, B.R. (1993): Effect of food additives on quality of salted pink perch. (Nemipterus japonicus). J. Food Sci. Technol., 30 (4): 261.

Kim, C.R. and Hearnsberger, J.O. (1994): Gram-negative inhibition by lactic acid culture and food preservatives on Catfish fillets during refrigerated storage. J. Food Sci., 59: 513-516.

Kim, C.R.; Hearnsberger, J.O.; Vickery, A.P.; White, C.H. and Marshall, D.L. (1995a): Extending shelf life of refrigerated catfish fillets during refrigerated storage. J. Food. Sci., 59: 513.

Kim, C.R.; Hearnsberger, J.O.; Vickery, A.P.; White, C.H. and Marshall, D.L. (1995b): Sodium acetate and Bifidobacteria increase shelf life of refrigerated cat fish fillets. J. Food Sci., 60: 25-27.

Kim, G.R.; Hearnsberger, J.O.; Vickery, A.P.; White, and Marshall, D.L. (1995): Extending shelf-life of refrigerated Catfish fillets using sodium acetate and monopotassium phosphate. J. Food Prot., 58 (6): 644-650.

Kondaiah, N.; Zeuthen, P. and Jul, M. (1985): Effect of chemical dips on unchilled fresh beef inoculated with E. coli, Streptococcus faecalis and Clostridium perfringens and stored at $30^{\circ} \mathrm{C}$ and $20^{\circ}$ C. J. Meat. Sci., 12: 17-30. 
Korshunove, V.M.; Untaeva, Z.A.; Smeianov, V.V.; Efimov, B.A.; Sarkisov, S.E.; Krymshokolava, Z.A.; Bainov, N.A.; Pikina, A.P. and Korshunova, O.V. (1999): The antagonistic activity of Bifidobacteria in vitro and vivo studied by using gnotobiological technology. Zh Mikrobiol. Immunobiol., (5): 72-75.

Kurmann, J.A. and Rasic, J.L. (1991): The health potential of products contaning Bifidobacteria. In therapeutic properties of fermented milks. R. K. Robinson. Elesvier. Appl. Sci., London and New York.

Laroia, S. and Martin, J.H. (1991): Methods for enumeration and propagating Bifidobacteria. Cult. Dairy Prod. J., 26 (2): 32.

Laskshmanan, P.T. and Gopakumar, K. (1996): Quality evaluation of iced stored major carps using K-value and fish tester (VI) reading. FOA Fisheries Report No. 563.

Licciardello, J.J. and Hill, W.S. (1978): Microbiological quality of commercial frozen minced fish blocks. J. Food. Prot., 41: 948952.

Lindgren, S.E. and Dobrogosz, W.J. (1990): Antagonistic activities of lactic acid bacteria in food and feed fermentations. FEMS, Microbiol. Lett. 87:149.

Mahmoud, Y.E. (1990): Studies on the sanitary condition of some Nile fishes marketed in Kalyobia Governorate. M.V.Sc. Thesis, Fac. Vet. Med. Moshtohor, Zagazig Univ.

Mahmoud, Y.E. (1994): Studies on frozen fish. Ph. D. Thesis. Fac. Vet. Med. Moshtohor. Zagazig Univ.

Marshall, D.L. and Jindal, V. (1997): Microbiological quality of cat fish frames treated with selected phosphates. J. Food. Prot., 60 (9): 1081 .

Martin, J.H. and Chou, K.M. (1992): Selection of Bifidobacteria for use as dietary adjuncts in cultured dairy foods. Tolerance to $\mathrm{pH}$ yoghurt. Cultured Dairy Prod. J. 27: 21.

Mehanna, N.S.; Sharaf, O.M.; Ibrahim, G.A. and Tawfik, A. (2002): Incorporation and viability of some probiotic bacteria in functional dairy food. (soft cheese). Egypt. J. Diary Sci., 30: 217-229.

Mendonca, A.F.; Molins, R.A.; Kraft, A.A. and Walker, H.W. (1989a): Effect of potassium sorbate, sodium acetate, phosphates and disodium chloride alone or in combination on shelf life of vacuum packaged pork chops. J. Food Sci., 54: 302-306. 
Mendonca, A.F.; Mollins, R.A.; Kraft, A.A. and Walker, H.V. (1989b): Microbiological, chemical and physical changes in fresh, vacuum packaged pork treated with organic acid salts. J. Food Sci., 54: 18 .

Mocking, G. and Machava, A.M. (1986): Storage life on ice of the bycatch from the shrimp fishery-fish processing in Africa.p.7480. In Proceedings of the FAO Expert Consultation on Fish Technology in Africa, No. 329. Lusaka, Zambia, 21-25 January 1985. FAO, Rom, Italy.

Modler, H.W.; Mekellar, R.C.; Goff, H.D. and Mackie, D.A. (1990): Using ice cream as a mechanism to incorporate Bifidobacteria and Fructooligosaccharides into the human diet. Gulf Dairy Food J., 25 (3): 4-8.

Mohamed, Rabab, M.K.M. (1990): Enterotoxigenic strains of Staphylococci in market fishes. M.V.Sc. Thesis, Fac. Vet. Med., Cairo Univ.

More, J. and Iriter, F. (1970): Introductory. $2^{\text {nd }}$ Ed. Macmillian Co. London.

Mosffer, M.A.; Dagal, A.L.; Wael, A.B. and Bazaraa, A. (1999): Extension of shelf life of whole and peeled shrimp with organic acid salts and BIfidobacteria. J. Food Prot., 62: 51-56.

Niazi, Z.M.; Refai, M. and Sawah, H. (1988): A study on the effect of freezing storage on the viability and enterotoxin. A production of toxigenic Staphylococcus aureus included in fluid medium and minced meat. J. Egypt. Vet. Med. Assoc. 48 (3): 397-405.

Nour, M.K. Hassan and Abosrea Nadia, A. (2005): Experimental studies on the effect of Bifidobacterium bifidum on Listeria monocytogenes and E. coli in ice-cream. J. Egypt. Vet. Med. Assoc., 65 (5): 179-192.

Okereke, A. and Montville, T.J. (1991): Bacteriocin inhibition of Clostridium botulism spores by lactic acid bacteria. J. Food Prot., 54: 349.

Person, D. (1984): Chemical analysis of Foods. $8^{\text {th }}$ Ed. Ronald's Kirk., Ronald Sawyer, Eagan.

Polledo, J.J.; Maria, L.G.; Moreno, M. and Ignacio, M. (1986): Importance of food handlers as a source of Enteropathogenic Staphylococci. Zentralbl. Bakteriol. Mikrobial. Hyg. Art. I. Orig. B. Hyg. 
Post, L.S.; Lee, D.A.; Solberg, M.; Furgang, D.; Specchio, J. and Garham, C. (1985): Development of botulinal toxin and sensory deterioration during storage of vacuum and modified atmosphere packaged fish fillets. J. Food Sci., 50-995.

Raccach, M. and Baker, R.C. (1978): Lactic acid bacteria as an antispoilage and safety factor in cooked mechanically deboned poultry meat. J. Food Prot., 41: 703-707.

Raj Liston, J. (1963): Effect of processing on public health bacteria in frozen sea food. Food Technol., 19: 53-60.

Ravn, Jorgensen, B.; Gibson, D.M. and Huss, H.H. (1988): Microbiological quality and shelf life prediction of chilled fish. Int. J. Food Microbiol. 6: 295.

Ray, B. (1992): Cells of lactic acid bacteria as food biopereservation. In Food Biopereservative of Microbial Origin. CRC Press, Inc., Boca Raton, FL.

Reddy, G.V.; Shahani, K.M.; Fried, B.A. and Chandan, R.C. (1984): Natural antibiotic activity of Lactobacillus acidophilus and bulgaricus. III. Production and partial purification of bulgarican from Lactobacillus bulgaricus. Cultured Dairy Prod. J. 19: 15.

Reddy, S.G.; Henrickson, R.L. and Olson, H.C. (1970): The influence pf lactic cultures on ground beef quality. J. Food. Sci., 35: 787790.

Reddy, S.G.; Herickson, R.L. and Olson, H. (1970): The influence of lactic cultures on ground beef quality. J. Food Sci., 35: 787.

Robinson, R.K. (1990): Survival of Bifidobacterium bifidum in health promoting yoghurt. S. Afr. Dairy Sci., 22: 43-46.

Rose, A.H. (1968): Physiology of microorganisms at low temperature. J. Appl. Bact. 31: 1.

Saad, M.S.; Abo-Bakr, M.L. and Yhia, E.A. (1991): Microbiological evaluation of some Nile fishes marketed in Kalyobia province. Zagazig Vet. J., 19 (1): 233-242.

Schaack, M. and Marth, E.H. (1988): Behavior of Listeria monocytogenes in skim milk during fermentation with mesophilic lactic acid starter cultures. J. Food Prot., 52: 600607.

Seback, N.H. (1998): Studies on quality of frozen fish. Ph. D. Thesis, Fac. Vet. Med. Beni-Suef, Cairo Univ.

Shewan, J.M. (1971): The microbiology of fish and fishery products-a progress report. J. Appl. Bacteriol. 34: 299-135. 
Soliman, Zeinab, I. and Shalaby, Amany, M. (2001): Effect of freezing and different cooking process on viability of $E$. coli and Staphylococcus aureus in fish fillets. J. Egypt. Vet. Med. Assoc., 61: 143-150.

Teraguchi, S.; Uehara, M.; Ogasa, K. and Mitsuoka, T. (1978): Enumeration of Bifidobacteria in dairy products. Jap. J. Bacteriol. 33: 753.

Thatcher, F.S. and Clark, D.S. (1978): Microorganisms in Food. $1^{\text {st }}$ Int. Comm. Microbiol. Specific. Foods. Toronto Univ. Press. Tronto and Buffalo, Canada. pp.5.

Unda, J.R.; Molins, R.A. and Walker, W. (1990): Microbiological and some physical and chemical changes in vacuum packaged beef steaks treated with combination of potassium sorbate, phosphate, sodium chloride and sodium acetate. J. Food Sci., 55: 323-326.

Vazquez, J.A.; Gonzalez, M.P. and Murado, M.A. (2005): Effect of lactic acid bacteria cultures on pathogenic microbiota from fish. Aquaculture, 245: 149-161.

Weber, F.C. and Schmidt, L.W. (1989): Colony count of Gram-negative bacteria in cold storage foods and water. Zentralbl Bakteriol. Mikrobiol. Hyg., 187: 181.

Wijsman, M.R.; Hereijgers, L.P.M. and Groote, J.M.F.H. (1989): Selective enumeration of Bifidobacteria in fermented dairy products. Neth. Milk Dairy J. 43: 395.

Woyewoda, A.D. and Bilgh, E.G. (1986): Effect of phosphate blends and stability of cod fillets in frozen storage. J. Food. Sci., 51 (4): 932.

Wu, C.Y. and Chen, H.C. (1980): The changes in bacterial flora of Metapenaeopsis barbatus during low temperature storage. J. Fish Soc. Taiwan, 7: 41-48.

Yehia, N.Y. (1996): Microbiological evaluation of farm fish in Kafr-Elshikh. M.V.Sc. Thesis, Fac. Vet. Med. Kafr El-Shikh, Tanta Univ.

Zhuang Rong-Yu; Huang Ten-Yao and Larry, R.B. (1996): Quality changes during refrigerated storage of packed shrimp and cat fish fillets treated with sodium acetate, sodium lactate or propyl Gallate. J. Food. Sci., 61: 241-261. 